\title{
GAMBARAN DATA ODONTOGRAM REKAM MEDIK GIGI DI BALAI PENGOBATAN RUMAH SAKIT GIGI DAN MULUT UNIVERSITAS SAM RATULANGI MANADO
}

\author{
${ }^{1}$ Hendry H. R. Poluan, ${ }^{2}$ Erwin Kristanto, ${ }^{2}$ Vonny N. S. Wowor \\ ${ }^{1}$ Mahasiswa Program Studi Kedokteran Gigi Fakultas Kedokteran \\ Universitas Sam Ratulangi Manado \\ ${ }^{2}$ Dosen di Program Studi Kedokteran Gigi Fakultas Kedokteran Universitas Sam Ratulangi \\ Email : hernandez_hendry@yahoo.com
}

\begin{abstract}
ABSTRAK
Prosedur identifikasi merupakan prosedur penentuan identitas individu, baik hidup maupun mati melalui perbandingan berbagai data dari individu yang diperiksa dengan data orang yang disangka sebagai individu tersebut. Identifikasi diperlukan karena status kematian korban memiliki dampak yang cukup besar pada berbagai aspek kehidupan pada keluarga yang ditinggalkan.Sesuai Undang-Undang Republik Indonesia No. 36 tahun 2009 Tentang Kesehatan, pemerintah dan masyarakat bertanggung jawab atas upaya identifikasi yang dilakukan.

Bagi para aparat penegak hukum dan pengadilan, pembuktian melalui gigi merupakan metode yang valid dan terpercaya, sebanding dengan nilai pembuktian sidik jari dan penentuan golongan darah. Odontogram merupakan data yang penting dalam proses identifikasi. Data odontogram merupakan salah satu data yang terlampir dalam rekam medik gigi.Data odontogram memuat data tentang jumlah, bentuk, susunan, tambalan, protesa gigi, dan sebagainya.Odontogram sedapat mungkin dibuat secara teliti sehingga dapat dibedakan dan diketahui secara pasti keadaan gigi dan jenis tindakan yang dilakukan.

Penelitian ini dilakukan untuk mengetahui gambaran data odontogram di BP-RSGMP Unsrat Manado. Sampel berjumlah 164 rekam medik gigi yang didapatkan dengan menggunakan rumus deskriptif kategorik. Hasil penelitian menunjukkan terdapat 164 (100\%) catatan odontogram dalam rekam medik, tidak adanya catatan odontogram berupa gambar saja, terdapat catatan odontogram berupa keterangan saja sebesar 32 sampel $(19,5)$ dan catatan odontogram yang terdapat gambar dan keterangan sebanyak 132 (80,5\%), serta 164 (100\%) catatan odontogram memiliki keterangan tentang waktu pembuatan odontogram dan 164 (100\%) catatan odontogram tidak memiliki catatan tentang pemutakhiran data sehingga tidak ada catatan yang termutakhir.
\end{abstract}

Kata kunci : Rekam medik gigi, odontogram

\begin{abstract}
Identification procedure is the procedure of determining the identity of individuals, both living and dead through the comparison of the data from the individual who checked with the data of persons suspected as the individual. Identification is needed because the status of the victim's death had a considerable impact on various aspects of life on the family left behind. According to the Law of the Republic of Indonesia No. 36 of 2009 Concerning health, the government and the people responsible for the identification efforts undertaken.

For law enforcement officers and the courts, through dental evidence is valid and reliable method, comparable with the evidential value of fingerprints and blood grouping. Odontogram is the data that is important in the identification process. Data odontogram is one of the data in the medical record attached teeth. Data odontogram contain data on the number, shape, composition, fillings, dental prostheses, and so on. Odontogram wherever possible be made carefully so that it can be distinguished and known for certain dental conditions and type of action taken.
\end{abstract}


This study was conductedto describethe datain theBP-RSGMP odontogramUnsratManado. The total sampling is164dentalmedical recordsobtainedby usingdescriptivecategoricalformula. The results showedthere were164(100\%) odontogramnotesinmedical records, nottherecords ofan imageodontogramcourse, there isadescription ofjustodontogramrecordof 32samples(19.5) andodontogramrecordscontainedas many as 132imagesand description(80, 5\%), and164(100\%) odontogramrecordshaveinformation about the timeof makingodontogramand164(100\%) odontogramrecorddoes nothavea record ofupdating the dataso thatno records areupdated.

Keyword : Dental medical record, odontogram

\section{PENDAHULUAN}

Beberapa tahun terakhir ini banyak kejadian bencana yang menyebabkan jumlah korban manusia yang besar. Penyebab bencana bermacam-macam, yakni akibat ulah manusia (bencana bom, kebakaran), bencana alam (banjir, longsor, gunung meletus), kecelakaan transportasi (darat, laut, udara) dan lainlain. Pada kasus-kasus seperti ini sering kita jumpai korban jiwa yang sulit dikenali akibat jenasahnya sudah rusak sehingga perlu dilakukan identifikasi. $^{1,2,3}$

Undang-undang Republik Indonesia No. 36 tahun 2009 Tentang Kesehatan pasal 118 menyebutkan bahwa mayat yang tidak dikenal harus dilakukan upaya identifikasi dan pemerintah, pemerintah daerah dan masyarakat bertanggung-jawab atas upaya identifikasi. ${ }^{5}$ Identifikasi diperlukan karena status kematian korban memiliki dampak yang cukup besar pada berbagai aspek kehidupan (aspek kemanusiaan, aspek sosial, aspek hukum, aspek ekonomi, aspek budaya) pada keluarga yang ditinggalkan. ${ }^{6}$

Prosedur identifikasi adalah prosedur penentuan identitas individu, baik hidup maupun mati, yang dilakukan melalui perbandingan berbagai data dari individu yang diperiksa dengan data dari orang yang disangka sebagai individu tersebut. ${ }^{9}$ Pada proses identifikasi korban dengan kerusakan tubuh yang parah (jenazah yang rusak, membusuk, hangus terbakar, potongan tubuh manusia atau kerangka) digunakan metodeidentifikasi dengan keakuratan yang cukup tinggi. Salah satu metode dimaksudadalah pemanfaatan gigi sebagai sarana identifikasi, yang dikembangkan dalam kedokteran gigi forensik. Menjelang akhir abad 20 dalam dekade delapan puluhan pemanfaatan kedokteran gigi forensik berkembang pesat terutama dalam situasi bencana yang memakan banyak korban jiwa, seperti kecelakaan pesawat terbang atau kapal laut, ledakan bom, kebakaran, bencana alam, dll. ${ }^{1}$

Benda bukti gigi sudah sejak lama disadari mempunyai peran yang besar dalam identifikasi personal dan pengungkapan kasus kejahatan. Bagi para aparat penegak hukum dan pengadilan, pembuktian melalui gigi merupakan metode yang valid dan terpercaya, sebanding dengan nilai pembuktian sidik jari dan penentuan golongan darah. ${ }^{6}$ Alasan yang dikemukakan mengapa gigi dapat dipakai sebagai sarana identifikasi yaitu karena gigi adalah bagian terkeras dari tubuh manusia yang komposisi bahan organik dan airnya sedikit sekali dan sebagian besar terdiri atas bahan anorganik sehingga tidak mudah rusak, selain itu terlindung karena berada dalam rongga mulut dan dilingkupi oleh basahnya air liur. Gigi baru lapuk pada suhu 200 derajat Celcius dan menjadi abu pada suhu 450 derajat Celcius. Manusia memiliki 32 gigi dengan bentuk yang jelas. Dengan demikian di dalam rongga mulut terdapat berbagai variasi keadaan gigi yaitu baik rusak, ditambal, dicabut, gigi tiruan, implant 
dan lain-lain. Fornes menerangkan bahwa kemungkinan terdapatnya dua orang dengan data gigi dan mulut yang identik yaitu satu berbanding dua miliar penduduk. Melalui pengamatan gigi geligi, kita dapat memperoleh informasi tentang umur, ras, jenis kelamin, golongan darah, ciri-ciri khas, bentuk wajah dan raut muka korban. ${ }^{1,4,6}$

PERMENKES

No:

269/MENKES/PER/III/2008 tentang rekam medik gigi yang merupakan berkas yang berisi catatan dan dokumen antara lain identitas, hasil pemeriksaan, pengobatan yang telah diberikan serta tindakan dan pelayanan lain yang telah diberikan kepada pasien. Catatan merupakan tulisan-tulisan yang dibuat oleh dokter gigi mengenai tindakantindakan yang dilakukan kepada pasien dalam rangka pelayanan kesehatan. Salah satu metode yang sering digunakan dalam odontologi forensik adalah pencatatan data gigi (odontogram) dan rahang yang dapat dilakukan dengan pemeriksaan manual, sinar-X, dan pencetakan gigi dan rahang. ${ }^{8}$ Odontogram memuat data tentang jumlah, bentuk, susunan, tambalan, protesa gigi dan sebagainya. Seperti halnya dengan sidik jari, maka setiap individu memiliki susunan gigi yang khas. Dengan demikian dapat dilakukan identifikasi dengan cara membandingkan data temuan post mortem dengan data pembanding ante mortem. Sedapat mungkin di dalam odontogram dicatat secara teliti mengenai keadaan gigi dan terapi yang akan dilakukan, sehingga dapat dibedakan dan diketahui secara pasti keadaan gigi dan jenis tindakan yang dilakukan.

Peranan data ante mortemyang sangat besar ditunjukkan antara lain pada beberapa kasus, seperti kasus Bom Bali I tahun 2002, dimana korban yang teridentifikasi berdasarkan gigi-geligi mencapai 56\%, kemudian pada tahun 2013 korban kecelakaan lalu lintas di Situbondo mencapai $60 \%$, dan tahun 2002 korban jatuhnya Pesawat Garuda di Jogyakarta mencapai $66,7 \%{ }^{1}$

Balai Pengobatan Rumah Sakit Gigi dan Mulut Universitas Sam Ratulangi Manado merupakan sarana kesehatan yang tentunya memiliki data rekam medik yang di dalamnya terdapat data odontogram. Oleh karena itu, dengan mengingat pentingnya peran odontogram dalam pembuatan rencana perawatan gigi secara menyeluruh, juga sangat berharga sebagai data untuk keperluan identifikasi, maka penulis merasa tertarik untuk mengambil data tersebut untuk dijadikan suatu penelitian mengenai gambaran data odontogram di Balai Pengobatan Rumah Sakit Gigi dan Mulut di Manado.

\section{BAHAN DAN METODE}

Penelitian ini merupakan jenis penelitian deskriptif yang mendeskripsikan tentang data odontogram dalam rekam medik gigi di Balai Pengobatan Rumah Sakit Gigi dan Mulut Universitas Sam Ratulangi.Populasi dalam penelitian ini adalah data rekam medik gigi di Balai Pengobatan Rumah Sakit Gigi dan Mulut Universitas Sam Ratulangi Manado.Besar sampel ditentukan berdasarkan sampel deskriptif kategorik yang diperoleh dengan rumus :

$$
\mathrm{n}=\frac{Z \alpha^{2} \times \mathrm{P} \times \mathrm{Q}}{d^{2}}
$$

$\mathrm{Z} \alpha=$ Deviat baku alfa

$\mathrm{P}=$ Proporsi penelitian yang diteliti

$\mathrm{Q}=1-\mathrm{P}$

$\mathrm{D}=$ Presisi

Berdasarkan rumus di atas diperoleh ukuran sampel sebagai berikut: 


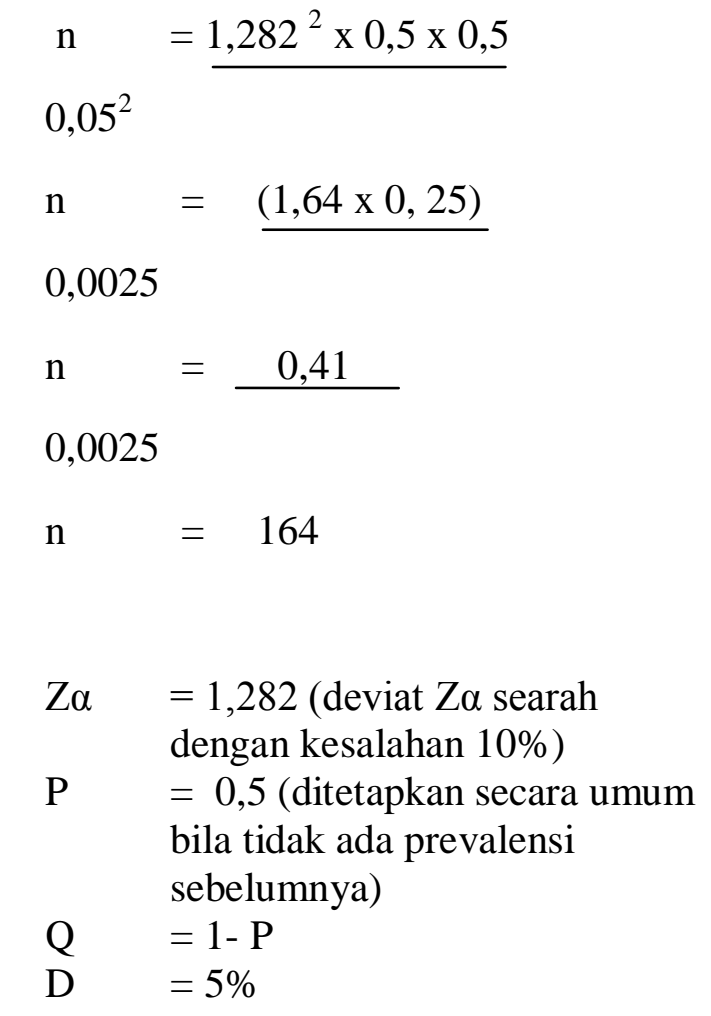

Uji kelayakan sampel:

$\mathrm{N} \times \mathrm{P}>5$

$164 \times 0,5=82$ (uji kelayakan terpenuhi)

Data yang dikumpulkan adalah data sekunder yang diperoleh dari data odontogram yang berada di BP-RSGM UNSRAT dan data primer yang diperoleh dari hasil pengumpulan data, sebagai berikut:

1. Melakukan rekapitulasi jumlah data rekam medik pasien di Balai Pengobatan Rumah Sakit Gigi dan Mulut Universitas Sam Ratulangi Manado.

2. Melakukan rekapitulasi jumlah data odontogram di Balai Pengobatan Rumah sakit Gigi dan Mulut.

3. Mendata kelengkapan data odontogram di Balai Pengobatan Rumah Sakit Gigi dan Mulut sesuai dengan Standar Nasional Rekam Medik Kedokteran Gigi.

\section{HASIL PENELITIAN}

BP-RSGM Unsrat berdiri tahun 2010 dan memiliki 4 lantai., merupakan Balai Pengobatan Gigi yang nantinya sebagai cikal bakal RSGM. BP-RSGM ini beralamatkan di Jl. Dr. Sutomo, Pusat Kota Manado dan dikelola oleh Universitas Sam Ratulangi. BP-RSGM merupakan wahana tempat pendidikan profesi PSKG-FK Unsrat, memberikan berbagai pelayanan seperti pencabutan gigi, penambalan gigi, pembuatan gigi palsu, pembersihan karang gigi, pembuatan alat ortodontik, dll yang ditangani oleh para tenaga dokter gigi yang merupakan dosen Unsrat dan tenaga dokter gigi anggota Persatuan Dokter Gigi Cabang Manado.

Kelengkapan catatan identitas dalam rekam medik gigi yang berisikan odontogram

Catatan identitas terletak pada bagian awal dari rekam medik gigi yang dibuat. Catatan tersebut meliputi nama, alamat, jenis kelamin dan nomor telepon. Kelengkapan catatan identitas pasien dalam rekam medik gigi yang berisikan odontogram dapat dilihat pada tabel $1 \mathrm{di}$ bawah ini:

Tabel 1. Distribusi berdasarkan kelengkapan catatan identitas pada catatan odontogram dalam rekam medik gigi

\begin{tabular}{ccccc}
\hline Catatan & Ada & \multicolumn{3}{c}{ Tidak } \\
\cline { 2 - 5 } $\begin{array}{c}\text { identitas } \\
\text { pasien }\end{array}$ & Jumlah & $\%$ & Jumlah & $\%$ \\
\hline Nama & 164 & 100 & 0 & 0 \\
Alamat & 164 & 100 & 0 & 0 \\
$\begin{array}{c}\text { Jenis } \\
\text { kelamin } \\
\text { Nomor } \\
\text { telepon }\end{array}$ & 164 & 100 & 0 & 0 \\
\hline
\end{tabular}

Hasil pada tabel 1 memperlihatkan kelengkapan identitas dalam catatan 
rekam medik gigi meliputi nama, alamat, jenis kelamin dan nomor telepon sejumlah $164(100 \%)$ lengkap.

Keadaaan catatan odontogram dalam rekam medik gigi

Catatan odontogram merupakan salah satu unsur yang harus ada pada rekam medik gigi sesuai dengan Standar Nasional Rekam Medik Gigi. Catatan odontogram sendiri dapat dikatakan lengkap dan sesuai apabila terdiri atas gambar serta keterangan gambar pada denah giginya.

Keadaan catatan odontogram di BPRSGMP UNSRAT Manado dapat dilihat pada tabel 2 di bawah ini.

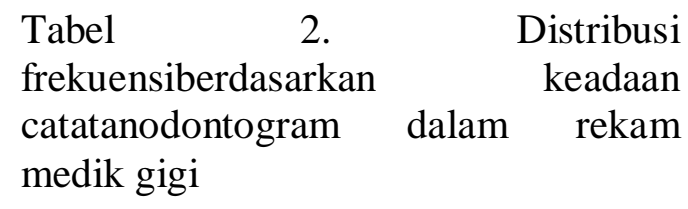

\begin{tabular}{lcc}
\hline $\begin{array}{l}\text { Keadaan catatan } \\
\text { odontogram }\end{array}$ & Jumlah & $\%$ \\
\hline Terdapat gambar & 0 & 0 \\
$\begin{array}{l}\text { Terdapat } \\
\text { keterangan }\end{array}$ & 32 & 19,5 \\
$\begin{array}{l}\text { Terdapat gambar } \\
\text { dan keterangan }\end{array}$ & 132 & 80,5 \\
\hline \multicolumn{1}{c}{ Total } & 164 & 100 \\
\hline
\end{tabular}

Data pada tabel 2 memperlihatkan tidak adanya catatan odontogram berupa gambar saja, terdapat catatan odontogram berupa keterangan saja sebesar 32 sampel $(19,5)$ dan catatan odontogram yang terdapat gambar dan keterangan sebanyak 132 (80,5\%).

Keadaan catatan pelengkap odontogram dalam rekam medik gigi di BP-RSGMP UNSRAT Manado

Pada rekam medik gigi selain terdapat odontogram, terdapat juga catatan yang melengkapi odontogram berupa catatan tentang keadaan occlusi, torus palatinus, torus mandibularis, palatum, supernumerary teeth, diastema, gigi anomali, serta keadaan lain-lain di dalam rongga mulut pasien. Catatan pelengkap odotogram dalam rekam gigi yang berisikan keadaan rongga mulut di BP-RSGMP UNSRAT Manado dapat dilihat pada tabel 3 di bawah ini.

Tabel 3. Distribusi berdasarkan keadaan catatan pelengkap odontogram dalam rekam medik gigi

\begin{tabular}{|c|c|c|c|c|}
\hline \multirow{2}{*}{$\begin{array}{l}\text { Catatan } \\
\text { pelengkap } \\
\text { odontogram }\end{array}$} & \multicolumn{2}{|c|}{ Ada } & \multicolumn{2}{|c|}{ Tidak } \\
\hline & $\mathrm{Jml}$ & $\%$ & $\mathrm{Jml}$ & $\%$ \\
\hline Occlusi & 164 & 100 & 0 & P \\
\hline Torus palatinus & 164 & 100 & 0 & 0 \\
\hline $\begin{array}{l}\text { Torus } \\
\text { mandibularis }\end{array}$ & 164 & 100 & 0 & 0 \\
\hline Palatum & 164 & 100 & 0 & 0 \\
\hline $\begin{array}{l}\text { Supernumerary } \\
\text { teeth }\end{array}$ & 164 & 100 & 0 & 0 \\
\hline Diastema & 164 & 100 & 0 & 0 \\
\hline Gigi anomali & 164 & 100 & 0 & 0 \\
\hline $\begin{array}{l}\text { Status } \\
\text { periodontal }\end{array}$ & 164 & 100 & 0 & 0 \\
\hline
\end{tabular}

Dapat dilihat catatan pelengkap odontogram yang berisikan catatan tentang occlusi, torus palatinus, torus mandibularis, palatum, supernumerary teeth, diastema, gigi anomali, status periodontal semuanya sebanyak 164 catatan $(100 \%)$ terisi secara lengkap.

Keterangan lain pada odontogram dalam rekam medik gigi

Keterangan lainnya pada odontogram terdiri atas waktu pencatatan dan pemutakhiran data. Kelengkapan lainnya pada catatan 
odontogram di BP-RSGMP UNSRAT Manado dapat dilihat pada tabel 4 berikut ini:

Tabel 4. Distribusi berdasarkan keterangan lain pada catatan odontogram dalam rekam medik gigi

\begin{tabular}{llcc}
\hline No & Ada & Tidak \\
\hline 1. & $\begin{array}{l}\text { Waktu pembuatan } \\
\text { odontogram }\end{array}$ & 164 & - \\
\hline 2. & $\begin{array}{l}\text { Dilakukan } \\
\text { pemutakhiran data }\end{array}$ & - & 164 \\
\hline
\end{tabular}

Hasil pada tabel 4memperlihatkan bahwa pada catatan odontogram terdapat sebanyak $164(100 \%)$ catatan tentang waktu pembuatan rekam medik gigi, sedangkan 164 (100\%) tidak ada catatan waktu pemutakhiran data.

\section{PEMBAHASAN}

Kelengkapan catatan identitas dalam rekam medik gigi yang berisikan odontogram

Pada bagian awal rekam medik gigi terdapat catatan identitas yang terdiri atas catatan nama, alamat dan jenis kelamin untuk membedakan pasien serta nomor telepon yang sewaktuwaktu bisa dihubungi. Data identitas pasien cukup diisi sekali saja pada saat pasien pertama kali datang, data lainnya dilengkapi sesegera mungkin pada kunjungan kedua. Data selalu disesuaikan jika ada perubahan seperti pindah alamat dan sebagainya.Berdasarkan hasil penelitian pada sampel catatan dalam rekam medik gigi di BP-RSGM Unsrat mengenai ketersediaan catatan identitas, didapatkan pada 164 (100\%) rekam medik gigi mempunyai catatan identitas. Hal ini dimungkinkan karena catatan itu BP-RSGM merupakan wahana tempat pendidikan mahasiswa tahap profesi di Program Studi Kedokteran Gigi Unsrat. Dengan demikian pengisian rekam medik harus dibuat lengkap. Kepatuhan mahasiswa dalam melengkapi isi rekam medik besar antara lain akibat adanya pengawasan dari para supervisor di klinik.

Keadaan catatan odontogram dalam rekam medik gigi di BP-RSGM Unsrat Manado

Petunjuk pengisian odontogram dalam Standar Nasional Rekam Medik Kedokteran Gigi mengharuskan pengisian odontogram terdiri atas gambar tentang perawatan atau tindakan pada gigi pasien dan keterangan dari gambar yang bersangkutan. ${ }^{10}$ Berdasarkan hasil penelitian di BPRSGM Unsrat mengenai keadaan catatan odontogram, didapatkan tidak adanya catatan odontogram berupa gambar saja, catatan berupa keterangan saja sebesar 32 sampel $(19,5)$ dan catatan odontogram yang terdapat gambar dan keterangan sebanyak 132 (80,5\%). Kondisi ini belum menggambarkan keadaan yang sebenarnya, karena keberadaan gambar dan keterangan tidak diperiksa kesesuaiannya. Bisa saja terjadi gambar yang ada tidak sesuai dengan keterangan yang dituliskan. Penulis sempat mengambil beberapa sampel untuk dicocokkan, dan ternyata belum semuanya sesuai. Hal ini menggambarkan bahwa pengisian Standar Nasional Rekam Medik Kedokteran Gigi. belum sepenuhnya dipatuhi, walaupun semua berkas rekam medik sudah dilengkapi denah odontogram.

Setiap pasien yang datang pada kunjungan pertama memiliki catatan odontogram. Formulir yang tersedia di BP-RSGM Unsrat sudah sesuai dengan Standar Nasional Rekam Medik Gigi dan pemeriksaan untuk setiap gigi yang dirawat maupun tidak dirawat 
dituliskan pada keterangan dalam catatan odontogram. Dalam pengisian simbol-simbol pada gambar sudah sesuai dengan Standar Nasional Rekam Medik Kedokteran Gigi tetapi pengisian gambar dalam denah gigi tidak sesuai dengan keterangan yang ada. Pemeriksaan dilakukan pada kunjungan selanjutnya, tetapi dalam gambar dan keterangan catatan odontogram tidak dirubah sehingga data odontogram dalam rekam medik gigi di Balai Pengobatan Rumah Sakit Gigi dan Mulut bukan catatan yang termutakhir, yang ada hanya catatan waktu pengisian odontogram pada kunjungan pertama.

Hal tersebut memperlihatkan bahwa keadaan catatan odontogram di BPRSGM Unsrat secara keseluruhan belum sepenuhnya memenuhi petunjuk pengisian IKodontogram Standar Nasional Rekam Medik Kedokteran Gigi yang seharusnya dilengkapi dengan gambar tindakan perawatan serta kondisi perawatan terakhir pada gigi pasien beserta keterangannya. ${ }^{10}$

Keadaan catatan pelengkap odontogram dalam rekam medik gigi di BP-RSGM Unsrat Manado

Keadaan dalam rongga mulut meliputi keadaan occlusi, torus palatinus, torus mandibularis, palatum, supernumerary teeth, diastema, gigi anomali, dan keadaan lain-lain harus terekam dengan benar dalam catatan rekam medik gigi. Berdasarkan hasil penelitian didapatkan catatan rekam medik gigi yang memiliki catatan tentang occlusi, torus palatinus, torus mandibularis, palatum, supernumerary teeth, diastema, gigi anomali, keadaan lainlain (status periodontal) sebesar 164 (100\%).

Hal tersebut memperlihatkan bahwa catatan pelengkap odontogram BP-
RSGM Unsrat sudah sesuai dengan petunjuk pengisian odontogram Standar Nasional Rekam Medik Kedokteran Gigi. ${ }^{10}$ Keadaan ini dimungkinkan karena pada pencatatan pertama kali pada rekam medik gigi yang dibuat, para mahasiswa profesi benar-benar diawasi, sehingga seluruh catatan tentang keadaan rongga mulut yang ada terisi secara lengkap.

Keterangan lain pada catatan dontogram dalam rekam medik gigi di BP-RSGM Manado

Standar Nasional Rekam Medik Kedokteran Gigi menjelaskan bahwa pencatatan waktu pemeriksaan terhadap seluruh gigi yang dilakukan perawatan harus diisi lengkap dan sesuai ketentuan pada kunjungan pertama. Pembuatan odontogram perlu diulangi atau dilengkapi setiap satu tahun, setiap kunjungan untuk control, atau jika pasien akan pindah kota/ dokter gigi pindah kota dan apabila sebelum satu tahun sudah sangat banyak restorasi permanen yang dilakukan. $^{10}$ Hasil penelitian menunjukkan pencatatan waktu pemeriksaan pertama kali telah dilakukan untuk 164 (100\%) rekam medik pasien, namun catatan tentang pemutakhiran data tidak ditemukan. Penulis berasumsi pemutakhiran data tidak dilakukan karena masih kurangnya kesadaran dan pengetahuan para petugas kesehatan mengenai pentingnya pemutakhiran data.

\section{SIMPULAN}

Dari hasil penelitian tentang gambaran data odontogram dalam rekam medik gigi di BP-RSGM Unsrat Manado sesuai Standar Nasional Rekam Medik Kedokteran Gigi, maka dapat diambil kesimpulan sebagai berikut:

1. Semua rekam medik gigi yang ada di BP-RSGM Unsrat Manado 
sudah memiliki catatan odontogram.

2. Data odontogram yang ada belum semuanya terisi dengan lengkap, dimana terdapat keberadaan data tentang catatan gambar atau keterangan odontogram yang belum sesuai.

3. Data odontogram meliputi catatan gambar dan keterangan belum semuanya sesuai.

\section{SARAN}

Berdasarkan hasil penelitian dan pembahasan sebelumnya, maka dapat diajukan saran-saran sebagai berikut :

1. Catatan odontogram dalam rekam medik gigi perlu dilengkapi sesuai dengan Standar Nasional Rekam Medik Kedokteran Gigi, dimana data odontogram berupa gambar perlu dilengkapi dengan keterangan, demikian sebaliknya.

2. Bagi tenaga medis yang bertugas di BP-RSGM Unsrat Manado perlu memperhatikan kesesuaian antara catatan gambar dalam data odontogram dengan keterangannya.

\section{DAFTAR PUSTAKA}

1. Riyadi, S. Pentingnya Pemeriksan Gigi untuk Keperluan Identifikasi dalam Pelayanan Kedokteran Gigi Forensik. RSIA Sumber Kasih. [cited 2013 Mei]. Available from : URL:

http://rsiasumberkasih.com/2011/10/ pentingnya-pemeriksan-gigiuntuk.html
2. Eddy S. DVI in Indonesia an Overview. DVI Workshop, Bandung; 2006.

3. Slamet P, Peter S, Yosephine L, Agus M. Pedoman Penatalaksanaan Identifikasi Korban Mati pada Bencana Massal. Jakarta: Departemen Kesehatan Republik Indonesia dan Kepolisian Negara Republik Indonesia; 2004. h.1-23

4. Idries, A, M. Pedomanilmu kedokteran forensik. Edisi pertama. Jakarta: Binarupa Aksara. 1997: P. 32-37

5. Undang-undang Republik Indonesia no. 36 tentang Kesehatan. Tahun 2009.

6. Admadja, D, S. Peran Odontologi Forensik dalam Penyidikan. [cited 2013 Mei]. Available from: URL: http://hanidipta.com/2010/03/ilmukedokteran-gigi-forensik.html

7. Peraturan Menteri Kesehatan Republik Indonesia Nomor 269/MENKES/ PER/III/2008 [cited 2013 Mei], Rekam Medis. Available from: $\quad$ URL: http//www.permenkesrekammedik.c om

8. Cardoza AR. Forensic Dentistry Investigation Protocols. In: Forensic Dental Evidence 2nd ed. CA:Elsevier; 2011:(4)86-88.

9. Saraf S. Forensic Odontology. In: Textbook of Oral Pathology. India: Jaypee;

10. Standar Nasional RekamMedik Kedokteran Gigi. Direktorat jenderal pelayanan medik departemen kesehatan RI, 2004 